Forest Reclamation Advisory No. 12

June 2015

\title{
RE-ESTABLISHING AMERICAN CHESTNUT ON MINED LANDS IN THE APPALACHIAN COALFIELDS
}

\author{
Michael French, Chris Barton, Brian McCarthy, Carolyn Keiffer, Jeff Skousen, Carl Zipper, and Patrick Angel
}

American chestnut (Castanea dentata) was formerly a major component of forests throughout the Appalachian coalfield and beyond. Chestnut's strong, lightweight wood was naturally rot-resistant, making it a preferred timber tree for many purposes. Unlike many other nut-producing trees that flower early in the year, American chestnuts flower in June and July, so they were less susceptible to a late freeze or frost that could damage the flowers. Due in part to its late flowering, American chestnuts produced a reliable and abundant nut crop that was an important source of nutrition for wildlife, livestock, and humans.

However, American chestnut has suffered severe decline throughout the USA; today, few living and mature American chestnut trees remain. This Forest Reclamation Advisory describes efforts to develop new American chestnut varieties, and reclamation and planting techniques for chestnut on mined lands.

\section{American chestnut's demise and restoration}

Beginning in the early 1900s, an introduced fungus known as the chestnut blight (Cryphonectria parasitica) devastated chestnut populations. American chestnuts were virtually eliminated as a canopy tree throughout its native range by the 1950s.

Early attempts at breeding disease-resistant trees that could restore chestnuts to the forest failed to produce a tree that had sufficient disease resistance and the ability to compete against other hardwoods. Founded in 1983, The American Chestnut Foundation's (TACF) mission is to restore American chestnut to eastern forests to benefit the environment, wildlife, and society. TACF focused on a breeding strategy to create a population of chestnuts that would incorporate the disease resistance of Chinese chestnut (Castanea mollissima) and retain the form and functional characteristics of American chestnut (Figure 1). This strategy crosses Chinese chestnuts and American chestnuts, then takes those offspring through a series of backcrosses and intercrosses to create trees with American traits and high levels of disease resistance. At each step of the process, trees are intentionally infected with the disease so that only trees with high levels of disease resistance and American characteristics are used for further breeding. In 2005, TACF began producing trees that are approximately 15/16 American chestnut, 1/16 Chinese chestnut in character and should have a high level of disease resistance (i.e. the $B_{3} F_{3}$ generation). TACF is calling this generation "Restoration Chestnuts $1.0^{\prime \prime}$, which implies that breeding efforts will continue to improve both disease resistance and American characteristics into the future. TACF is now testing Restoration Chestnuts 1.0 for their disease resistance and other characteristics.

\section{American chestnut's ecology, distribution, and abundance}

Historical literature and examination of sprouts and remnants of older trees indicates that American chestnut preferred rich, non-calcareous, well-drained, acidic to slightly acidic soils ( $\mathrm{pH} 4-6$ ), and was a dominant component of slopes and ridge-tops throughout Appalachia but grew poorly in wet soils (Abrams and Ruffner, 1995; Abrams and McCay, 1996; Braun, 1950; Burke, 2011; Frothingham, 1912; Paillet, 2002; Russell, 1987; Wang et al., 2013). Chestnut's abundance on the landscape varied with many factors including land use history, but it reportedly accounted for approximately $25 \%$ of the virgin timber in the southern Appalachians and more than $50 \%$ of the timber in some second- growth forests (Braun, 1950, Buttrick, 1915; Frothingham, 1912).

By all accounts, American chestnut's sheer dominance in many stands made it eastern North America's most important nut producer and one of the most important timber producers. The loss of American chestnut from our forests is often described as the greatest ecological disaster of the $20^{\text {th }}$ century. 


\title{
THE AMERICAN CHESTNUT FOUNDATION'S BACKCROSS BREEDING PROGRAM
}

\begin{abstract}
TACF's backcross breeding program begins by crossing an American chestnut and a Chinese chestnut. This is followed by three successive generations of crossing back to American chestnut trees to restore American characteristics. In between each breeding step, the trees are inoculated with blight fungus (Cryphonectria parasitica) and only those trees showing strong blight resistance and American characteristics are chosen to breed additional generations. For the final two generations, trees with proven blight resistance are intercrossed with each other to eliminate genes for susceptibility to blight introduced from the American parents.
\end{abstract}

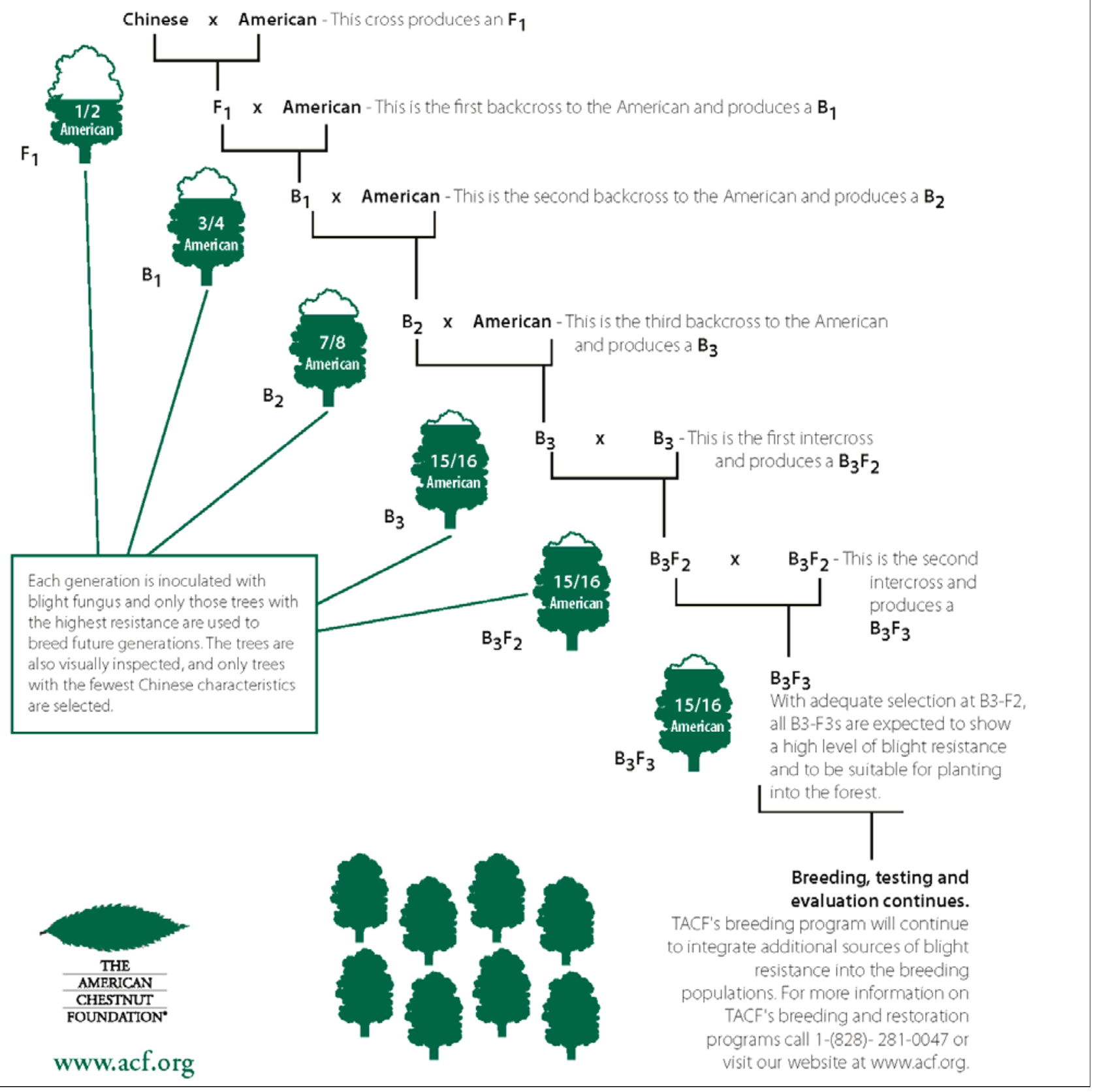

Figure 1. The American Chestnut Foundation's breeding strategy to develop a population of chestnuts that will display the growth and form characteristics of American chestnut while retaining the blight resistance of Chinese chestnuts.(Courtesy of The American Chestnut Foundation). 
The Forestry Reclamation Approach for chestnut restoration

During the early 2000s in anticipation of disease resistant chestnuts, ARRI cooperators and researchers began testing the suitability of mined lands reclaimed with the Forestry Reclamation Approach (FRA) for chestnut introduction. Cooperators and researchers have planted and monitored pure American chestnuts and backcross chestnuts on FRA-reclaimed lands throughout the Appalachians. Once chestnut varieties with disease resistance and American characteristics become widely available, mine operators will be able to plant those seedlings along with other Appalachian hardwoods and reclamation species on mine sites.

The TACF strategy for chestnut restoration includes early establishment of small populations throughout the chestnut's former range. These initial groups of trees ("founder populations") are intended to serve as seed sources and to aid natural dissemination to other areas.

Establishing founder populations of chestnuts on mined lands has been of interest to TACF researchers for numerous reasons. The first is the overlap of American chestnut's native range and the Appalachian coalfield (Figure 2). Furthermore, many mining disturbances occur on upper slopes and ridge-tops where chestnuts were formerly a dominant component of the forest, potentially making former surface mines ideal locations for chestnut introduction. In addition, research has demonstrated that chestnut can be successful when planted on mines that have been reclaimed using the Forestry Reclamation Approach (FRA). Also, mining disturbances reclaimed using the FRA may limit the establishment of root-rot pathogens (Phytophthora spp.) that have hindered TACF's breeding efforts in the southern Appalachians (James, 2011).

Phytophthora is a water mold that favors wet soils or those with high water holding capacities; the welldrained soils created by the FRA may limit Phytophthora establishment. Lastly, surface mines reclaimed with the FRA are essentially "blank slates", where conditions benefitting chestnut establishment can be created. Vegetative competition for nutrients, sunlight, and water can be reduced through the proper implementation of step 3 of the FRA (see Forest Reclamation Advisory \#6; Burger et al. 2009), whereas chestnuts planted in existing forests and old fields face competition from established vegetation.

\section{Legend}

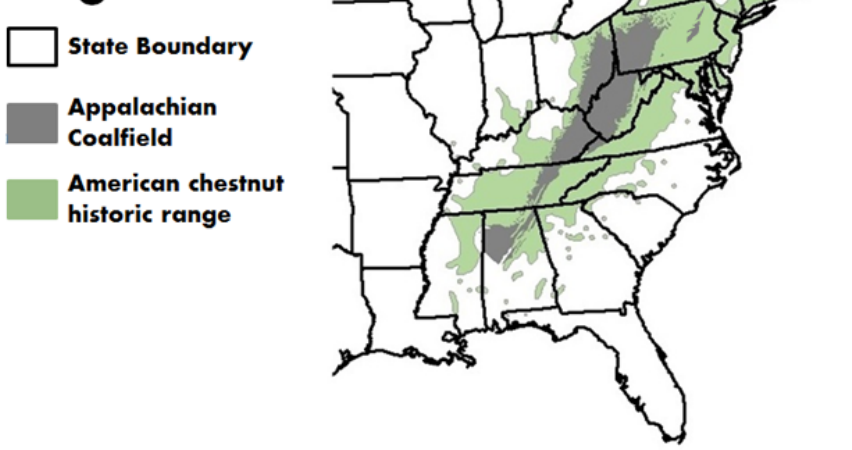

Figure 2. The native range of American chestnut (Little 1977) overlaid on the Appalachian coalfield.

\section{Prior research and work}

Studies of early backcross chestnut $\left(B_{1} F_{3}, B_{2} F_{3}\right.$, and $B_{3} F_{2}$ ) growth and survival on sites that implemented FRA techniques as a part of active mining operations have offered encouraging results. Two studies in West Virginia found survival rates of 40 to $70 \%$ for backcross chestnuts planted as seed ("direct-seeded") after four growing seasons, with the authors noting that the survival for the total chestnut stock fell within the survival range of other hardwoods in similar planting trials (Skousen et al., 2013). A study in eastern Kentucky found survival rates from $41 \%$ to $60 \%$ for sheltered, direct-seeded backcross chestnuts after five growing seasons (Barton et al., 2013). Similar trials on FRA sites in Ohio, Pennsylvania and Tennessee exhibited similar survival rates ( $>40 \%$ average survival for backcrosses after 5 growing seasons) (Bizzari, 2013). A study comparing groundcover effects on backcross chestnut survival on an FRA site in southwestern Virginia showed $48 \%$ to $73 \%$ survival after two growing seasons and showed that bare root seedlings initially performed better than chestnuts that were direct-seeded (Fields-Johnson et al., 2012). Bare root seedlings also performed better than chestnut seeds in an Ohio study (McCarthy et al., 2010). Several planting methods have been shown to give adequate initial survival, including potted seedlings, direct seeding, and bare root plantings; all of these methods are suitable for introducing chestnuts to mined lands (Fields-Johnson et al., 2012; French et al., 2007, Skousen et al., 2013). A Tennessee study found dense ground cover comprised of annual ryegrass (Lolium perenne) inhibited chestnut growth (Klobucar, 2010). 


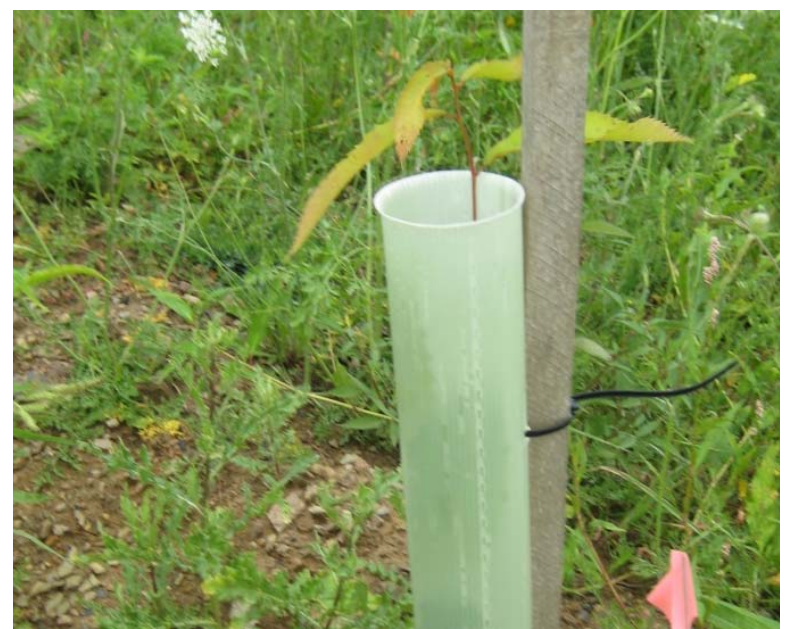

Figure 3. A Restoration Chestnut 1.0 planted as seed emerging from a $24^{\prime \prime}$ tree shelter after 3 months on an active mine in Ohio.

Legacy surface mines (those reclaimed using conventional post-SMCRA reclamation and not reforested with native trees) and abandoned mine lands (AML) are also potential launching points for blight-resistant chestnut introduction, although less work has been done to identify establishment methods that are most suitable for such sites. Restoration Chestnut $1.0\left(B_{3} F_{3}\right)$ plantings on $A M L$ sites in 2012 and 2013 have used a limited number of seed and seedlings and early success varied from 32 to $100 \%$ survival after 1 season (French and Edwards, unpublished data). Bauman et al. (2013a) found that a cross-ripped legacy site in Ohio had $73 \%$ survival of bare root chestnuts after six growing seasons and that the chestnuts began producing nuts in the fourth growing season. Similar observations of chestnut seed production by the fourth or fifth growing season (Figure 4) have been made by the authors and ARRI collaborators on active FRA sites in Ohio, Kentucky, Tennessee, and West Virginia. Mitigation of compaction on a legacy mine in Ohio enabled greater colonization of chestnut root-tips by beneficial mycorrhizal fungi, which likely led to higher survival and growth rates when compared to the untreated controls (Bauman et al. 2013b).

TACF is currently creating mixed hardwood/American chestnut forests on mined lands that implement the FRA as a part of a Conservation Innovation Grant (CIG) awarded to TACF by the US Natural Resources Conservation Service in 2011. Each of the 12 CIG plantings is approximately 30 acres in size and has a mixed hardwood component with Restoration Chestnuts 1.0 planted randomly throughout. The Restoration Chestnuts 1.0 are planted at 20 per acre as one-year old (1-0) bare root seedlings in a mix with other 1-0 bare root hardwoods for 680 trees per acre total. This will demonstrate how Restoration

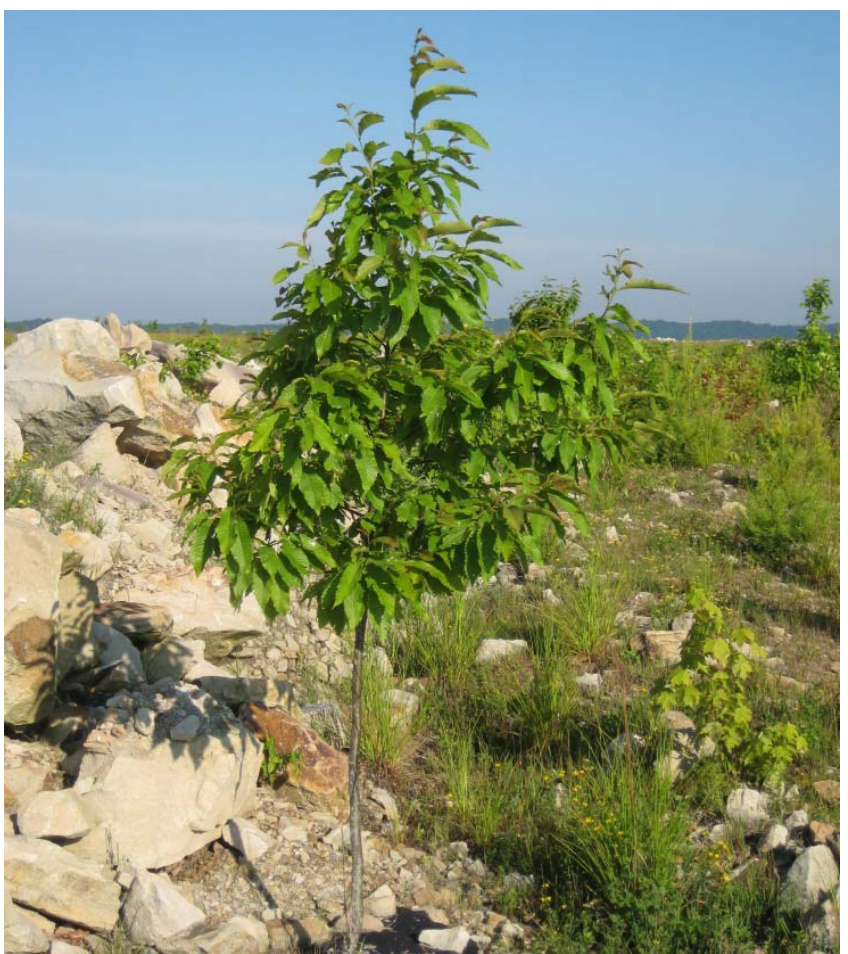

Figure 4. A 5 year-old backcross chestnut on a reclaimed mine in West Virginia. Many of the trees on this site were producing male and female flowers.

Chestnuts 1.0 compete against other commonly used native hardwoods in a mixed hardwood reforestation planting. A direct-seeded, 1-acre progeny test to examine varying degrees of blight resistance in the Restoration Chestnut 1.0 population is also a component of each of these plantings. Several of these plantings have had $>80 \%$ germination and survival for direct-seeded chestnuts and $\geq 90 \%$ survival for bare root planted chestnuts after one growing season (French et al., unpublished data).

\section{Biotic and abiotic considerations for establishing chestnuts on mined lands} Many active mine sites that implement the five steps of the FRA (see Forest Reclamation Advisory \#2; Burger et al., 2005) meet the criteria of American chestnut's site requirements in historical accounts. Although every step of the FRA is important, particular attention should be paid to avoiding compaction on areas to be reforested with chestnuts. Compacted soils are often poorly drained, and chestnuts are known to perform poorly in wet soils (Rhoades et al., 2003). Phytophthora root rot on American chestnut seedlings was found to be greater in soils with higher moisture content (Rhoades et al., 2003).

Additionally, soil pH varies greatly on mined lands and should be tested before planting to ensure that it is near chestnut's preferred range ( $\sim 4$ to 6 ). These soil $\mathrm{pH}$ levels can usually be achieved through use of salvaged soil and/or weathered overburden for soil 
reconstruction, as per FRA recommendations (Skousen et al., 2011). New mine soils constructed of unweathered overburden usually will not be suitable for American chestnut plantings due to high soil pH, high salinity, or both.

Microsite factors should also be taken into account when planting. Gilland and McCarthy (2012) found that chestnut seedlings planted near the edge of existing forest $(\sim 5 \mathrm{~m})$ showed significantly lower growth and survival than seedlings planted away from the forest edge (20-50m). Additionally, they found that chestnuts fared better when some groundcover was present, and that seedlings planted on the sides of end-dumped FRA piles survived better than when planted on the tops of the piles (Gilland and McCarthy 2012).

When planting bare root chestnuts, no special handling is necessary. ARRI recommendations for preparing, handling, storing, and planting hardwoods are sufficient for chestnuts (see Forest Reclamation Advisory \#7; Davis et al., 2010). Chestnuts are known to be fast-growing and 1-0 seedlings are generally of adequate size to be vigorous. However, care should be taken to obtain seedlings from nurseries that do not have Phytophthora, if such assurance can be obtained.

When direct-seeding chestnuts, 18 -to-24 inch tree shelters should be used to prevent unacceptable losses from rodent predation and to avoid the problems associated with the use of tall tree shelters (Figure 3) (McCarthy et al., 2010; Sena et al., 2014; Skousen et al., 2013). Deer, rodents, and other herbivores are known to consume chestnut foliage, bark, and seeds. In areas with dense deer or elk populations, it may be necessary to construct fencing or wire cages around seedlings to prevent browsing and seedling losses. In Tennessee, fertilizer application at the time of planting was found to increase growth rates in the first two years (de Lima et al., 2011; Miller et al. 2011).

For establishing chestnut plantings on legacy mines, one should refer to recommendations in Forest Reclamation Advisory \#11 (Burger et al., 2013). Again, soil pH should be tested before planting and soil amendments applied if necessary, and competition from existing vegetation should be controlled.

\section{Summary and future work}

Many field planting trials have shown that Appalachian mined lands reclaimed with the FRA provide an opportunity for introducing blight-resistant chestnuts into eastern USA forests. The level of disease resistance in TACF's population of backcross chestnuts will not be known for several years so continued monitoring will be necessary. However, TACF will continue increasing blight resistance in the chestnuts seedlings that it is distributing for planting. Research has found that mine reclamation sites can be planted to establish founder populations of blight-resistant chestnuts that could then spread through natural processes into surrounding forests (Jacobs, 2007). There is still much to be learned about establishing chestnuts as a part of a mixed hardwood forest on mined lands; further research is ongoing.

The lessons learned from these trials may also play a role in re-establishing other native tree species that are being threatened by exotic pests and diseases. For example, mined lands are currently being tested to re-introduce American elms that are resistant to Dutch elm disease.

The American Chestnut Foundation considers efforts by ARRI and other organizations (such as Green Forests Work) to create productive and biodiverse forests on active mining operations, legacy mines, and AMLs a high priority. As larger numbers of Restoration Chestnuts 1.0 are produced, TACF intends to contribute more for reclamation projects. However, demand for blight-resistant chestnuts will outpace supply for many years to come. Full implementation of the FRA will be important to TACF decisions concerning allocation of blight-resistant chestnut stock for mine reclamation plantings.

\section{Literature cited}

Abrams M.D., and D.M. McCay, 1996. Vegetation-site relationships of witness trees (1780-1856) in the presettlement forests of eastern West Virginia. Canadian Journal of Forest Research 26: 217-224.

Abrams M.D., and C.M. Ruffner. 1997. Physiographic analysis of witness tree distribution (1765-1789) and present forest cover through north central Pennsylvania. Canadian Journal of Forest Research 25: 659-668.

Barton C.D., K.Ward, H. Angel. 2013. Continued monitoring of American chestnut restoration sites on surface mined land in Kentucky - Final report. The American Chestnut Foundation.

Bauman J.M., C. Cochran, B.C. McCarthy, and C.H. Keiffer. 2013a. American chestnut's role in the ecological restoration of coal-mined landscapes. The Journal of The American Chestnut Foundation 5:27 15-18.

Bauman J.M., C.H. Keiffer, S. Hiremath, B.C. McCarthy. 2013b. Soil preparation methods promoting ectomycorrhizal colonization and American chestnut Castanea dentata establishment in coal mine restoration. Journal of Applied Ecology 50: 721-729.

Bizzari L.E.. 2013. An Experimental Assessment of Blight-Resistant American Chestnut Success on Reclaimed Mine Lands Across Central Appalachia. M.S. thesis, Ohio University.

Braun E.L. 1950. Deciduous Forests of Eastern North America. New York: Hafner. 596 p.

Burger J., V. Davis, J. Franklin, C. Zipper, J. Skousen, C. Barton, and P. Angel. 2009. Tree compatible ground covers for reforestation 
and erosion control. Forest Reclamation Advisory No. 6. US Office of Surface Mining, ARRI.

Burger J., D. Graves, P. Angel, V. Davis, and C. Zipper. 2005. The forestry reclamation approach. Forest Reclamation Advisory No. 2. U.S. Office of Surface Mining, ARRI.

Burger J., C. Zipper, P. Angel, N. Hall, J. Skousen, C. Barton, and S. Eggerud. 2013. Establishing native trees on Legacy surface mines. Forest Reclamation Advisory No. 11. US Office of Surface Mining, ARRI.

Burke K.L. 2011. The effects of logging and disease on American chestnut. Forest Ecology and Management 261: 1027-1033.

Buttrick P.L. 1915. Commercial uses of chestnut. American Forestry 21: $960-968$.

Davis V., J. Franklin, C. Zipper, C., and P. Angel. 2010. Planting hardwood tree seedlings on reclaimed mine land in Appalachia. Forest Reclamation Advisory No. 7. US Office of Surface Mining, ARRI.

De Lima V., J.A. Franklin, and D.S. Buckley. 2011. Tree response to substrate and grading treatments on quarry overburden. In R.I. Barnhisel (Ed.) Proceedings of National Meeting of the American Society of Mining and Reclamation, Bismarck, ND June 11 - 16.

Fields-Johnson C.W., J.A. Burger, D.M. Evans, and C.E. Zipper. 2012. American chestnut establishment techniques on reclaimed Appalachian surface mined lands. Ecological Restoration 30:2 99105.

French M.E., C. Barton, D. Graves, P.N. Angel, F.V. Hebard. 2007. Evaluation of mine spoil suitability for the introduction of American chestnut hybrids in the Cumberland Plateau. In: Barnhisel, R.I. (ed.) 30 Years of SMCRA and Beyond, Gillette, WY, 2007. American Society of Mining and Reclamation.

Frothingham E.H. 1912. Second growth hardwoods in Connecticut. Forest Service Bulletin No. 96. Washington: US Department of Agriculture. $70 \mathrm{p}$.

Gilland K.E. and B.C. McCarthy. 2012. Reintroduction of American chestnut (Castanea dentata) on reclaimed mine sites in Ohio: Microsite factors controlling establishment success. Northern Journal of Applied Forestry 29(4): 197-205.

James, J. 2011. Phytophthora: the Stealthy Killer Part 2 The Challenge to Develop a Phytophthora-Resistant Chestnut. The Journal of The American Chestnut Foundation. 4:25 4-8.

Jacobs D.F. 2007. Toward development of silvical strategies for forest restoration of American chestnut (Castanea dentata) using blight-resistant hybrids. Biological Conservation 137: 497-506.

Klobucar, A, 2010. Competitive Interactions between Appalachian Hardwoods and Different Groundcovers on Reclaimed Mine Sites. M.S. Thesis, University of Tennessee.

Little, E.L., Jr., 1977, Atlas of United States trees, volume 4, minor Eastern hardwoods: U.S. Department of Agriculture Miscellaneous Publication 1342

McCarthy B.C., K.E. Gilland, J.M. Bauman, and C.H. Keiffer. 2010. Factors affecting performance of artificially regenerated American chestnut on reclaimed mine sites. pp. 582-597. in R.I. Barnhisel (ed.) Proceedings, American Society of Mining and Reclamation.

Miller C.R., J.A. Franklin, and D.S. Buckley. 2011. Effects of soil amendment treatments on American chestnut performance and physiology. In R.I. Barnhisel (Ed.) Proceedings of National Meeting of the American Society of Mining and Reclamation, Bismarck, ND June $11-16$.

Paillet F.L. 2002. Chestnut: history and ecology of a transformed species. Journal of Biogeography 29: 1517-1530.

Rhoades C.C., S.L. Brosi, A.J. Dattilo, and P. Vincelli. 2003. Effect of soil compaction and moisture on incidence of Phytophthora root rot on American chestnut (Castanea dentata) seedlings. Forest Ecology and Management 184: 47-54.
Russell E.W.B. 1987. Pre-blight distribution of Castanea dentata (Marsh.) Borkh. Bulletin. Torrey Botanical Club 114: 183-190.

Sena K., H. Angel, and C. Barton. 2014. Influence of tree shelters and weed mats on growth and survival of backcrossed chestnut seedlings on legacy minelands in eastern Kentucky. Journal of the American Society of Mining and Reclamation. 3(2):41-63.

Skousen J., T. Cook, L. Wilson-Kokes, and E. Pena-Yewtukhiw. 2013. Survival and growth of backcross chestnut seeds and seedlings on surface mines. Journal of Environmental Quality 42: 690-695.

Skousen J., C.E. Zipper, J.A. Burger, C. Barton, P. Angel. 2011. Selecting materials for mine soil construction when establishing forests on Appalachian mine sites. Forest Reclamation Advisory No. 8. US Office of Surface Mining, ARRI.

Wang G.G., B.O. Knapp, S.L. Clark, B.T. Mudder. 2013. The Silvics of Castanea dentata (Marsh.) Borkh., American Chestnut, Fagaceae (Beech Family). US Forest Service, Southern Research Station. General Technical Report SRS-173.

\section{Acknowledgements}

This Advisory was prepared with cooperation and assistance provided by Green Forests Work (http://greenforestswork.com/) and The American Chestnut Foundation (http://www.acf.org/). Photos used in this document were taken by Michael French. Faculty and researchers from the following universities and organizations contributed to this Forest Reclamation Advisory: American Birds Conservancy, Berea College, Green Forests Work, Indiana University of Pennsylvania, Miami $(\mathrm{OH})$ University, Ohio State University, Ohio University, Pennsylvania State University, Purdue University, Southern Illinois University, Stephen F. Austin State University, The American Chestnut Foundation, US Forest Service, US Geological Survey, US Office of Surface Mining Reclamation and Enforcement, University of Kentucky, University of Maryland, University of Tennessee, Virginia Tech, West Virginia University, and Wilkes University. Thanks to Patricia Donovan, Virginia Tech, for preparing the map.

\section{Authors}

Michael French (michael@acf.org), The American Chestnut Foundation, Asheville, NC.

Chris Barton (barton@uky.edu), University of Kentucky, Lexington, KY.

Brian McCarthy (mccarthy@ohio.edu), Ohio University, Athens, OH.

Carolyn Keiffer (KeiffeCH@muohio.edu), Miami University, Department of Botany, Middletown, $\mathrm{OH}$.

Jeff Skousen (jskousen@wvu.edu), West Virginia University, Morgantown, WV.

Carl Zipper (czip@vt.edu), Virginia Tech, Blacksburg, VA.

Patrick Angel (pangel@osmre.gov), US Office of Surface Mining Reclamation and Enforcement, U.S.D.I., London, KY 